\title{
Cognitive Outcomes and their Relation to some of the Skills of Motor Analysis for Basketball Coaches in Upper Egypt
}

\section{* Dr/ Walid Ibrahim Ahmed Al-Baseet}

\section{Introduction:}

Knowledge is one of the most important goals of sports education programs, namely knowledge of the laws, rules and details of performance and tactic for various sports activities, physical and motor fitness, and Physical, skillful and tactical performance.

Laila Farahat (2001) highlighted the role of knowledge in sports as one of the objectives of physical education and fitness programs whether for students or players. They must be familiar with the law and rules of the types of sports activity tactics. Students and practitioners of sports activities should be expected to learn about the importance of sports practice and the scientific basis upon which knowledge and information about sports activities should be increased at all levels. (9: 32, 31).

The cognitive outcome is the final outcome of what the coach acquires during the programs and curricula that he is subject to during his preparation as a coach capable of reaching the upper levels of his players and maintaining these levels.

The technical aspects associated with performance analysis are one of the most important trends recently formed in sports science, which aims to improve performance and increase its effectiveness based on the extraction of true and valid data that reflect the essence and nature of performance.

Glazier (2010) reports that performance analysis has emerged as a separate branch of sports science over the past decade. The general framework of this science is to combine biomechanics in sports analysis and symbolic analysis concerned with limiting performance components. (19: 625)

The qualitative analysis is of great importance to the athlete in understanding the characteristics of movement performance and technical skills in various sports 
activities. Glazier \& Robins (2012), Knudson (2007) agree that one way to increase the sportsmen understanding of movement patterns is their ability to apply analysis techniques by which they can observe and evaluate the sequence of the movement itself according to its meaning in traditional biomechanics, and they can also study the engineering characteristics of sports movement in a soft way. (20: 121), (22: 214)

Although cognitive analysis is subjective, it involves a personal assessment of the quality of the movement, but requires systematic action, knowledge of the details of movement performance, and knowledge of the science associated with the analysis. Knudson (2007) states that making qualitative analysis is objective and scientific requires the use of a structured approach by the analyst, including "needs analysis in light of the basic mechanical biomechanics of the movement."

$\mathrm{He}$ adds that qualitative analysis requires a good understanding of the technical performance or interactions of the movement in a particular sport or during training. (22: 38)

Because of the peculiarities of qualitative analysis, it plays an important role in sports training. Payton \& Bartlett (2008) states that qualitative analysis is still used in training to provide detailed feedback to the coach to improve performance, in the context of performance analysis, to distinguish between individuals when judging performance,. It is also used in descriptive performance comparisons. (16: 4)

Hall (2011) adds that movement analysis cannot be performed arbitrarily, but should be carefully planned. The evaluator should have a good knowledge of the biochemical properties of the movement. (21: 41)

Leighton \& Gierl (2009) states that knowledge assessment is the measurement of the level of achievement and the assessment of the knowledge the coach possesses through participation in educational or training programs. Cognitive tests are used as assessment tools. (25:27) 
The acquisition of knowledge and information related to motor performance or sportive skill is a prerequisite for qualitative analysis. Bartlett (2007) states that knowledge is a prerequisite for qualitative analysis. There are two types of information the analyst uses when diagnosing motor skill: the characteristics of a performer's technique and performance results. (16: 35)

Knowledge and information related to qualitative motor analysis are a personal experience, which is of great importance in qualitative analysis. Hall (2011) states that the ability of the sportsman to analyze the quality of the movement varies according to personal experience. In most cases, the high level of skill or movement improves the analyst's ability to focus attention on critical elements of performance.(21: 42)

\section{Research Issue:}

The researcher observed deficiencies in the cognitive outcomes of the basketball coaches through observation and some personal interviews vary according to the training age, qualification and number of years of experience. The number of specialized courses obtained by the coach and the inability of the coach to evaluate performance or diagnose errors for different levels of clubs. This may be due to the difference or confusion of their cognitive outcomes. This may be due to the difference or confusion of their cognitive outcomes. In the belief of the researcher the importance of measuring the cognitive outcomes of the coach in the preparation and work, the study was to determine the cognitive outcomes and its relationship with the skills of qualitative motor analysis of basketball coaches in Upper Egypt, which should be included in the training program for basketball coaches through measuring cognitive outcomes.

\section{Research Objective:}

Measuring cognitive outcomes and their relation to some of the skills of motor analysis for basketball players in Upper Egypt.

\section{Research Questions:}

What level of cognitive outcomes for basketball players in Upper Egypt in some tasks 
of motor analysis (observation analysis)?

Are there differences of statistical significance in the cognitive outcomes of the skill of observation and analysis among the basketball coaches in Upper Egypt due to the variables (age, qualification, number of years of experience, number of training courses)?

What is the relationship between cognitive outcomes and the skills of motor analysis (observation - analysis) in basketball coaches in Upper Egypt?

\section{Research Terms:}

Qualitative analysis, and self-judgment on the quality of human movement, in order to provide the most appropriate interventions to improve performance. (26: 11)

Qualitative

Analysis

Models: Lists the performance details, monitoring stages of implementation, and the technical errors of the performer, while submitting the intervention plans without their application. (24: 17)

\section{Related Studies:}

The study of Tariq Mohammed Jaber (2016) (8) entitled "Structrual knowledge and its relation to the training behavior of the football coaches in the Arab Republic of Egypt" which aims to evaluate the structural knowledge and its relation to the training behavior of football coaches in the Arab Republic of Egypt. The researcher used the descriptive method and the sample was selected from the faculty members in the faculties of Physical Education and football coaches in Arab Republic of Egypt and those registered in the Egyptian Federation of Football 2015/2016. (157) coach s attended the sessions of the African Federation to obtain the license (c) and (b) in Assiut and Menia Governorates. The researcher used the personal interview and the cognitive knowledge test to collect data for football coaches in Arab Republic of Egypt and the measure of training behavior for football coaches in Upper Egypt by Emad Mokhtar Abdel Ghaffar. The most important results were the weakness of the level of knowledge of the football coaches in the Arab Republic of Egypt, where it reached an acceptable level of $29.30 \%$, followed by a low 
level of $22.29 \%$. A good level in the third level was $17.83 \%$, then a very low level of $14.65 \%$. Then came a very good level, and came another excellent level of the ranking by $4.46 \%$.

The study of "Mohammed Hussein Marzouk" (2015) (12) entitled "Structural Knowledge and Its Relation to Instructional Practices of Physical Education Teachers" which was designed to evaluate the structural knowledge and its relation to the teaching practices of the teachers of physical education in the preparatory stage. The researcher used the descriptive method in the method of case study on a sample included (195 teachers) of the teachers of physical education and the researcher used the personal interview. The test of the structural knowledge of the teachers of physical education was prepared by the researcher in addition to the note card teaching practices of the teachers of physical education were prepared by the researcher. The most important results were that the test of structural knowledge distinguishes between teachers with excellent and weak levels in the aspects of structural knowledge. The use of a note card teaching practices helps to identify the strengths and weaknesses in the performance of physical education teachers during the application of the physical education lesson.

El-Baroudy study (2011) (18) entitled "The impact of an educational program using qualitative analysis on the cognitive field and the performance of the front somersault on the jumping horse for students of the Faculty of Physical Education / Assiut University" in order to identify the impact of an educational program using qualitative analysis on the field of knowledge and the performance of the front somersault on the horse jumping for of the Faculty of Physical Education. The descriptive approach was used and the research sample was chosen in a deliberate manner. It consisted of 18 students who could perform the skill under study at a rate of 6-7 points. The IQ ranged between 3-3.A test was conducted to evaluate the cognitive level of the sample (recall, cognition, application, structure and 
analysis) and evaluation by qualitative analysis of the four tasks (preparation, observation, diagnosis, and therapeutic intervention) and using (Gangstead and Beveridge) models to evaluate the frontal fissure on the hands. The most important results were: The students 'grades were categorized as follows: Total score in cognitive level tests Degrees on the points of the cognitive test axes "Preparation, observation, diagnosis, and therapeutic intervention" Students' degrees in the cognitive field "Recollection, understanding, application, analysis, "and students score in the frontal somersault skill performance on the hands on the jumping horse.

Bakhit \& Mohamed study (2010) (15) entitled qualitative analysis to evaluate the technical performance in some shooting competitions in order to identify the technical description of the stages of performance, and identify the most technical errors affecting the level of performance in shooting competitions (push the shot, throw the spear, and topple the hammer). The descriptive approach was used in a "case study" manner. The main sample was selected from the registered junior shooting players in the Assiut Area of Athletics under (20) years. The sample was (15) players and the pilot sample was (36) players. (Jangsted \& Webvredge) and (Hay \& Reed) models were used for observation, and video camera and projector as data collection tools. The most important results were: The application of the proposed evaluation resulted in the identification of correct technical performance and identification of technical errors in shooting races. The study recommended using technical performance assessment during training and competition, and using the Gangesed \& Webvredge and Hay \& Reid models to identify technical performance errors.

\section{Research Procedures: Research Approach:}

The researcher used the descriptive method (survey studies) to suit nature of the study.

\section{Research Sample:}

Basketball coach $s$ in Republic of Egypt registered with the Egyptian Basketball 
Federation records 2017/2018 season. The sample was selected of (45) intentional coach of basketball coaches in Assiut, Sohag, Qena and Aswan Governorates (Registered with the Egyptian Basketball Federation)

\section{Research Tools:}

The researcher used the cognitive test consisting of qualitative motor analysis tasks (observation, analysis) as a tool to assess the cognitive level of the sample under study.

\section{Cognitive Test Design:}

The researcher followed the following steps when designing the cognitive test under study:

Reference survey of previous studies related to the research subject.

Identify the main axes of the cognitive test according to the objectives of the research.

Formulation of cognitive level measurement questions related to the functions and models of qualitative motor analysis and their respective answers under the main axes of the test.

Distribution of questions of measuring the level of knowledge in equal proportions of each of them on the test axes.

The test was presented in its preliminary form to referees with expertise in the field of research to:

Identify the clarity of the formulation of cognitive test questions.

Correlate the questions of measuring the level of knowledge to the axes listed.

State the comprehensiveness and adequacy of the proposed answers in expressing the questions of the axes.

Estimate the ratio of the referees' agreement on the test in its initial form.

\section{Codification of the cognitive test:}

Validation of study tools:

First: Validation of the

Referees

(Virtual

Validation):

The

researcher

formulated

preliminary

questions for the cognitive test, annex (2) based on the subject of the research and its objectives and questions, after careful reading and access to previous studies related to the problem of research, to identify the content of the validity of the questions of knowledge testing by the referees, and delete, add and modify what they consider of the terms. 12 questions were formulated for each of the research axes (observation - analysis). They were formulated according to 
Bloom's classification of knowledge and levels of thinking (remembering, understanding, application, analysis, evaluation, creativity and innovation), so that the number of questions in the cognitive test become (48) questions where they were presented to experts - Annex (1). The following table shows the percentage of experts' agreement on the terms of the questionnaire in terms of the degree to which the term is related to the axis - the degree of clarity of the phrase. The researcher has agreed $(75 \%)$ and more to the opinions of experts to accept, reject or modify the phrase.

Table (1)

Ratio of experts' agreement on the terms of the questionnaire in terms of degree of correlation and clarity $(N=11)$

\begin{tabular}{|c|c|c|c|c|c|}
\hline \multicolumn{3}{|c|}{ Axis 1 } & \multicolumn{3}{|c|}{ Axis 2} \\
\hline Term & $\begin{array}{l}\text { Clarity } \\
\text { Ratio }\end{array}$ & $\begin{array}{c}\text { Correlation } \\
\text { Ratio }\end{array}$ & Term & $\begin{array}{l}\text { Clarity } \\
\text { Ratio }\end{array}$ & $\begin{array}{c}\text { Correlation } \\
\text { Ratio }\end{array}$ \\
\hline & QY.Y & $1 \ldots$ & & $\Lambda \varepsilon . \wedge$ & NTr.V \\
\hline & $1 \ldots$ & $1 \ldots$ & & 9 q. $^{\prime}$ & 91.4 \\
\hline & $91 . \varepsilon$ & $1 \ldots$ & & $1 \ldots$ & $1 \ldots$ \\
\hline & $9 \cdot .7$ & $1 \ldots$ & & $1 \ldots$ & $1 \ldots$ \\
\hline & $1 \ldots$ & $1 \ldots$ & & $1 \ldots$ & $1 \ldots$ \\
\hline & $1 \ldots$ & $1 \ldots$ & & $1 \ldots$ & $1 \ldots$ \\
\hline & $91 . Y$ & $9 . .0$ & & $91 . r$ & 91.1 \\
\hline & $9 \cdot . V$ & $9 \cdot .1$ & & $9 \cdot .5$ & $\wedge \wedge .9$ \\
\hline & QY.Y & $91 . r$ & & $94 . r$ & 91.7 \\
\hline & 94.0 & $9 Y . Y$ & & 91.1 & $9 \cdot .7$ \\
\hline & $9 \cdot .1$ & $9 \cdot . \varepsilon$ & & $9 \cdot .7$ & $1 \ldots$ \\
\hline & $9 Y .1$ & 91.1 & & $9 Y . \varepsilon$ & $\wedge 9 . \wedge$ \\
\hline
\end{tabular}

Table (1) shows that the percentage of clarity and the correlation of the terms to the axes according to the opinions of the experts ranged between $(88.9 \%)$ and $(100 \%)$, indicating the consensus of the experts on the clarity of the terms and their correlation to the axes.

Second, Validation of the internal consistency of the tool: The researcher applied the test on a pilot sample of (7) basketball coaches from outside the study sample to 
find out the validation of the internal consistency of the test by calculating the correlation coefficient between the degree of each of the test questions in the total degree of the axis, to which the question belongs, to calculate Person's correlation coefficient. The researcher calculated the internal consistency of the subjects of the axes (observation analysis). The results are as shown in the following tables:

\section{Table (2)}

Pearson correlation coefficients for (observation) axis terms

\begin{tabular}{|c|c|c|c|}
\hline $\begin{array}{l}\text { Question } \\
\text { No. }\end{array}$ & $\begin{array}{c}\text { Correlation } \\
\text { coefficient }\end{array}$ & Question No. & $\begin{array}{c}\text { Correlation } \\
\text { coefficient }\end{array}$ \\
\hline & $* * . .7 \cdot V$ & 7. & **..OYY \\
\hline & $* *, . \leqslant \leqslant 0$ & 8. & $* * .77 \Lambda$ \\
\hline & **. oro & 9. & **..Tr \\
\hline & $* * .0 \vee T$ & 10. & $* * . . T V Y$ \\
\hline & $* * . .7 Y q$ & 11. & $* *$. . $\vee 0$. \\
\hline & $* * . . \Sigma \Lambda T$ & 12. & $* * .07 \mathrm{~V}$ \\
\hline
\end{tabular}

** D at the level of significance 0.01 and less

Table (2) shows that the values and statistical function correlation coefficients between the score of the questions and the total score of the second axis (observation) ranged between $(0.445)$ for the second question and (0.750) for the fifth question, all positive at the level of 0.01 or 0.05 or less, A high degree of internal consistency and the correlation of the axis to its individualities, reflecting a high degree of honesty for the test paragraphs.

Table (3)Parson correlation coefficients for (analysis) axis terms

\begin{tabular}{|c|c|c|c|}
\hline $\begin{array}{l}\text { Question } \\
\text { No. }\end{array}$ & $\begin{array}{c}\text { Correlation } \\
\text { coefficient }\end{array}$ & $\begin{array}{l}\text { Question } \\
\text { No. }\end{array}$ & $\begin{array}{c}\text { Correlation } \\
\text { coefficient }\end{array}$ \\
\hline & $* * . . \leqslant \leqslant 7$ & 7. & $* *, . \vee \leqslant 9$ \\
\hline & $* * .071$ & 8. & $* * . .791$ \\
\hline & **. Trर & 9. & $* * . .7 V V$ \\
\hline & **..7Y & 10. & $* * . .0 \wedge r$ \\
\hline & $* * .09 V$ & 11. & $* * . .710$ \\
\hline & $* *$ * . $1 \wedge 0$ & 12. & $* * . .00 \mathrm{~V}$ \\
\hline
\end{tabular}

** D at the level of significance 0.01 and less

Assiut Journal For Sport Science Arts 
Table (3) shows that the correlation coefficients between the score of the questions and the total score of the third axis (analysis) ranged between 0.446 for the first question and 0.749 for the seventh question. All of these values are positive and statistically significant at 0.01 or 0.05 , of the internal consistency and correlation of

\section{Table (4)}

Alpha-cronbach coefficient values for the study tool" test"

\begin{tabular}{|c|c|c|}
\hline Axes & Alpha-cronbach & half-interval \\
\hline Observation & $\because \wedge \wedge 1$ & $\because \wedge \vee \leqslant$ \\
\hline Analysis & $\cdot . \wedge V Y$ & $\cdot . \wedge 7 \wedge$ \\
\hline $\begin{array}{l}\text { General stability of } \\
\text { the test }\end{array}$ & $\because \wedge \wedge \varepsilon$ &.$\wedge T r$ \\
\hline
\end{tabular}

Table (4) shows that the alpha-cronbach stability coefficients of the study instrument are statistically acceptable. The values of alpha cronbach for the pilot sample were 0.884 , while the stability values for the exploratory sample ranged between 0.881 and all are accepted statistical stability coefficients which indicates that the test has a high degree of stability.

Statistical Processes:

The statistical treatments were carried out using the SPSS version 17 to produce the the axis to its individuality and reflects a high degree of validity for the test terms.

Stability of the cognitive test:

The researcher used the alpha-cronbach equation and the half-interval to verify the stability of the test. Table (4) shows the alpha-cronbach coefficients and the halfinterval of the test. following variables: Frequency

- Percentage - Arithmetic mean

- Standard deviation -

Validation of internal consistency - Alpha Cronbach coefficient - T test - “one-way analysis of variance"

\section{Review and Discuss Results:}

To answer the first question, which states: "What is the level of cognitive outcomes of the basketball players in Upper Egypt in the tasks of qualitative motor analysis (observation analysis?) The frequencies and the percentage of correct 
answers as well as the frequency, percentage of incorrect answers, arithmetic averages and standard deviations of axial - Analysis) for basketball players in Upper Egypt were calculated.

Level of cognitive outcomes for basketball Coach $s$ (under-search):

\section{Table (5)}

Levels of basketball coach $\mathrm{s}$ in the measurement of cognitive outcomes $N=45$

\begin{tabular}{|c|c|c|c|c|c|}
\hline Test & Lev & & $\begin{array}{l}\text { Number } \\
\text { of coach } s\end{array}$ & Ratio & Ka 2 \\
\hline \multirow{6}{*}{$\begin{array}{l}\text { Measuring } \\
\text { cognitive } \\
\text { outcomes }\end{array}$} & Very weak & $\begin{array}{c}\text { From } 0 \% \\
\text { to less } \\
\text { than } \\
30 \%\end{array}$ & v & $\% 10.00$ & \multirow{6}{*}{17.710} \\
\hline & Weak & $\begin{array}{c}\text { From } \\
30 \% \text { to } \\
\text { less than } \\
50 \%\end{array}$ & 1. & $\%$ \% Y.Y & \\
\hline & Acceptable & $\begin{array}{c}\text { From } \\
50 \% \text { to } \\
\text { less than } \\
65 \%\end{array}$ & 11 & $\% \quad r \leq . \leq 0$ & \\
\hline & Good & $\begin{array}{c}\text { From } \\
65 \% \text { to } \\
\text { less than } \\
75 \%\end{array}$ & $\wedge$ & $\% \backslash \vee . \vee V$ & \\
\hline & very good & $\begin{array}{c}\text { From } \\
75 \% \text { to } \\
\text { less than } \\
85 \%\end{array}$ & 7 & \% & \\
\hline & Excellent & $\begin{array}{l}\text { From } \\
85 \% \text { to } \\
100 \%\end{array}$ & $r$ & $\% 7.7 \mathrm{~V}$ & \\
\hline
\end{tabular}

The value of $\mathrm{Ka} 2$ tabular is at $0.05=15.809$

Table (5) shows the existence of statistically significant differences between the levels of coaches in measuring the cognitive outcomes of basketball players in Upper Egypt in favor of the coaches who achieved an acceptable 
level at a significant level of 0.05 .

Table (5) also shows the weakness of the cognitive outcomes of the basketball players. The most coaches (11) were at an acceptable level of $24.45 \%$, followed by a weak level $(10)$ by $22.22 \%$ and a good level in the third level of (8) coach by $17.77 \%$, and a very poor level of (7) coach by $15.55 \%$, and a very good level (6) $(13.34 \%)$, and the last level was excellent and the number of (3) coach by $6.67 \%$, which is the lowest percentage of coach $\mathrm{s}$ in the test of cognitive outcomes.

The researcher attributed the weakness of the level of cognitive outcomes for basketball coaches (under study) to:

Many of them do not have academic preparation well.

The lack of training courses that the coach receives during his training.

Table (6)

Frequency and percentages of correct and incorrect answers to cognitive questions in the observation axis

\begin{tabular}{|c|c|c|c|c|c|c|}
\hline \multirow{2}{*}{$\begin{array}{l}\text { Level of } \\
\text { thinking }\end{array}$} & \multirow{2}{*}{ Sr. } & \multirow{2}{*}{$\begin{array}{l}\text { Cognitive } \\
\text { Questions }\end{array}$} & \multicolumn{2}{|c|}{ "Correct Answers } & \multicolumn{2}{|c|}{ Incorrect Answers } \\
\hline & & & Frequency & Percentage & Frequency & Percentage \\
\hline \multirow{3}{*}{ Remember } & 1 & $\begin{array}{l}\text { In observation } \\
\text { stage: }\end{array}$ & r. & $\% \leqslant \varepsilon . \varepsilon$ & ro & $\% 07.7$ \\
\hline & 2 & $\begin{array}{l}\text { Observation } \\
\text { strongly } \\
\text { depends on: }\end{array}$ & rv & $\% \wedge r . r$ & $\wedge$ & $\% \backslash \vee . \wedge$ \\
\hline & \multicolumn{2}{|c|}{$\begin{array}{l}\text { Total and } \\
\text { percentage }\end{array}$} & r^.0 & \% ס ס & 17.0 & $\%$ \% \\
\hline
\end{tabular}

The coach did not receive specialized training courses.

The weakness of the administrative aspects obtained by the coach within the training courses.

Weak training content for coaches.

The concept of assessment for basketball coaches is unclear.

Lack of interest on the part of Egyptian Basketball Federation officials in coaches.

Egyptian Basketball Federation officials don't encourage coaches to join the courses.

This is consistent with Afaf Othman (2014), (6), Smith (1999) (27), Amin alKhuli (1990), and Issam Metwalli (2011), and the study of Hisham Abdel Halim (2013) (14).

First: the axis of observation 
Follow Table (6)

Frequency and percentages of correct and incorrect answers to cognitive questions in the observation axis

\begin{tabular}{|c|c|c|c|c|c|c|}
\hline \multirow{2}{*}{$\begin{array}{l}\text { Level of } \\
\text { thinking }\end{array}$} & \multirow{2}{*}{ Sr. } & \multirow{2}{*}{$\begin{array}{l}\text { Cognitive } \\
\text { Questions }\end{array}$} & \multicolumn{2}{|c|}{ Correct Answers } & \multicolumn{2}{|c|}{ Incorrect Answers } \\
\hline & & & Frequency & Percentage & Frequency & Percentage \\
\hline \multirow{3}{*}{ Understanding } & 3 & $\begin{array}{l}\text { The organized } \\
\text { outlook of the } \\
\text { human motor } \\
\text { observation } \\
\text { includes: }\end{array}$ & rV & $\% 7$. & 11 & $\% \varepsilon$ \\
\hline & 4 & $\begin{array}{l}\text { Components } \\
\text { of the } \\
\text { observation } \\
\text { theory of: }\end{array}$ & rt & $\% \leqslant \wedge .9$ & r & $\% 01.1$ \\
\hline & \multicolumn{2}{|c|}{$\begin{array}{ll}\text { Total and } \\
\text { percentage }\end{array}$} & $r \leq .0$ & $\% 0 \leqslant 0$ & $r \cdot .0$ & $\% \leqslant 0.0$ \\
\hline \multirow{3}{*}{ Application } & 5 & $\begin{array}{l}\text { One of the } \\
\text { important } \\
\text { keys in } \\
\text { developing } \\
\text { observation: }\end{array}$ & iv & $\% r \vee . \wedge$ & rA & \% \%r.r \\
\hline & 6 & $\begin{array}{l}\text { The distance } \\
\text { between the } \\
\text { observed and } \\
\text { the motor is } \\
\text { important in: }\end{array}$ & r & $\% \circ \vee . \wedge$ & 19 & $\% \leqslant r . r$ \\
\hline & \multicolumn{2}{|c|}{ Total and percentage } & YI.0 & $\% \leqslant \vee .0$ & Tr.O & $\%$ Or.o \\
\hline \multirow{3}{*}{ Analysis } & 7 & $\begin{array}{l}\text { skill } \\
\text { observation } \\
\text { based on } \\
\text { importance } \\
\text { depends on }\end{array}$ & rt & $\% 0 \cdot .1$ & rt & $\% \leqslant \wedge .9$ \\
\hline & 8 & $\begin{array}{l}\text { Open skills } \\
\text { depend on: }\end{array}$ & 19 & $\% \leqslant r . r$ & rT & $\% \circ \vee . \wedge$ \\
\hline & \multicolumn{2}{|c|}{$\begin{array}{ll}\text { Total and } & \text { and } \\
\text { percentage } & \end{array}$} & r) & $\% \leqslant 7.0$ & $r \varepsilon$ & $\% \leqslant 7.0$ \\
\hline \multirow[t]{2}{*}{ Evaluation } & 9 & $\begin{array}{l}\text { Some skills } \\
\text { depend on } \\
\text { observing } \\
\text { balance }\end{array}$ & 10 & ים. & r. & $\%$ \%ั. У \\
\hline & 10 & $\begin{array}{l}\text { Examples of } \\
\text { good lengthy } \\
\text { observation } \\
\text { include: }\end{array}$ & 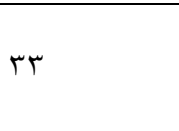 & ret & ir & $\%$ \%५. \\
\hline
\end{tabular}


Follow Table (6)

Frequency and percentages of correct and incorrect answers to cognitive questions in the observation axis

\begin{tabular}{|c|c|c|c|c|c|c|}
\hline \multirow{3}{*}{$\begin{array}{l}\text { Level of } \\
\text { thinking }\end{array}$} & \multirow{2}{*}{ Sr. } & \multirow{2}{*}{$\begin{array}{l}\text { Cognitive } \\
\text { Questions }\end{array}$} & \multicolumn{2}{|c|}{ Correct Answers } & \multicolumn{2}{|c|}{ Incorrect Answers } \\
\hline & & & Frequency & Percentage & Frequency & Percentage \\
\hline & $\begin{array}{l}\text { Tot } \\
\text { perc }\end{array}$ & ntage & $r \leq$ & $\% \leqslant 7.0$ & r) & $\% \leqslant 7.0$ \\
\hline \multirow{3}{*}{$\begin{array}{l}\text { Creativity and } \\
\text { innovation }\end{array}$} & 11 & $\begin{array}{l}\text { Beginners in } \\
\text { motor skill } \\
\text { usually show } \\
\text { performance: }\end{array}$ & $\varepsilon r$ & $9 \pi .4$ & r & 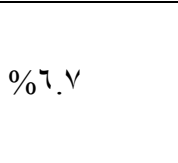 \\
\hline & 12 & $\begin{array}{l}\text { The layout in } \\
\text { the } \\
\text { observation } \\
\text { is done }\end{array}$ & $\varepsilon r$ & $9 \pi .4$ & r & $\%\urcorner \cdot \vee$ \\
\hline & $\begin{array}{l}\text { Tot } \\
\text { perc }\end{array}$ & ntage & $\varepsilon r$ & $\% 9$ \%.० & r & $\% 7.0$ \\
\hline \multicolumn{3}{|l|}{ Grand Total } & TV & $\%^{\top}$. & 11 & $\%$ \% \\
\hline
\end{tabular}

Table (7)

The average and standard deviation of knowledge levels for Bloom's division of the observation axis for basketball coaches in Upper Egypt

\begin{tabular}{|c|c|c|c|c|}
\hline $\begin{array}{l}\text { Level of } \\
\text { thinking }\end{array}$ & $\begin{array}{l}\text { Total } \\
\text { score }\end{array}$ & $\begin{array}{c}\text { Arithmetic } \\
\text { average }\end{array}$ & $\begin{array}{l}\text { standard } \\
\text { deviation }\end{array}$ & Ranking \\
\hline $\begin{array}{l}\text { Creativity and } \\
\text { innovation }\end{array}$ & r & $1 . \wedge \varepsilon$ & $\cdot r v$ & 1 \\
\hline Remember & r & $1 . T V$ & .79 & T \\
\hline Understanding & r & 1.99 &.$V 7$ & $r$ \\
\hline Evaluation & r & $1 . \cdot V$ & .01 & $\varepsilon$ \\
\hline Application & r & .90 & $\because V \leqslant$ & 0 \\
\hline Analysis & T & .91 & .7 & 7 \\
\hline $\begin{array}{l}\text { Observation } \\
\text { Axis Average }\end{array}$ & Kr & v.lT & $1 . \wedge r$ & - \\
\hline \multicolumn{5}{|c|}{$\begin{array}{l}\text { Table (6), (7) shows that } \\
\text { the level of knowledge of the } \\
\text { qualitative motor analysis skills } \\
\text { related to the observation axis } \\
\text { of the basketball coaches in } \\
\text { Upper Egypt is } 7.13 \text {, while the }\end{array}$} \\
\hline \multicolumn{3}{|c|}{ Assiut Journal For Sport Science Arts } & & \\
\hline
\end{tabular}


cognitive test $(0.60 \%)$, and the general average of the total of the incorrect answers at the observation axis was (40\%), and a detailed presentation of the results of the cognitive test of the levels of thinking according to Bloom's special division of the task of observation in the tasks of qualitative motor analysis.

This indicates that the cognitive test questions for the observation axis of the functions of the qualitative motor analysis in the mathematical field, which were developed in the light of the Bloom division, were low in the cognitive levels (observation - analysis) and by less than $50 \%$, indicating that there is a problem in the observation task of the qualitative motor analysis.

This means that the coach does not have a clear strategy in observing the player's motor performance, and that what is applied is based on personal experience and lacks the scientific standards of structured observation.

This is in line with what Knudson (2013), "Bartlett" (2007), and Capel (2004) said that "The strategy of structured observation should focus on what and how the movements are observed and focus on the critical characteristics of the movement identified as the task of preparation and prioritization. (23:01), (16: 52), (17:52)

Through the cognitive test, it is clear that the coach lacks the important observation requirements in the qualitative motor analysis indicated by Bartlett (2007), namely:

Implement the structured observation strategy developed for the preparation task.

Collect information about the movement of video recordings.

Focus the observation, for example on the stages of movement.

Determine where movement is observed (preference points), including considerations for other qualitative patterns.

Limit the number of observations. (16:47)

Through the results of the cognitive test, it is clear that basketball coaches lack the strategic objectives of the sports performance observation method. The structured observation strategy aims at 
providing a database of motor performance by organizing the collection of information. (2002), Knudson \& Morrison (2002) note that the goal of a structured observation strategy is to provide data related to movement performance, so all forms of movement must be taken care of and understood, which the teacher can store around the human movement, which includes gathering and interpreting the information rather than assessing its quality. (7: 225), (13: 122), (24: 115)

\section{Third: Analysis Axis}

\section{Table (8)}

Frequency and percentage of correct and incorrect answers to cognitive questions in the analysis axis

\begin{tabular}{|c|c|c|c|c|c|c|}
\hline \multirow{2}{*}{$\begin{array}{ll}\text { Level } & \text { of } \\
\text { thinking } & \\
\end{array}$} & \multirow{2}{*}{ Sr. } & \multirow{2}{*}{$\begin{array}{l}\text { Cognitive } \\
\text { Questions }\end{array}$} & \multicolumn{2}{|c|}{ Correct Answers } & \multicolumn{2}{|c|}{ Incorrect Answers } \\
\hline & & & Frequency & Percentage & Frequency & Percentage \\
\hline \multirow[t]{3}{*}{ Remember } & 1 & $\begin{array}{l}\text { To improve } \\
\text { motor } \\
\text { performance to } \\
\text { correlate an } \\
\text { action with a } \\
\text { previous action is } \\
\text { of the principles }\end{array}$ & $r \varepsilon$ & \%or.r & r) & $\% \leqslant 7 . \vee$ \\
\hline & 2 & $\begin{array}{l}\text { Evaluation is } \\
\text { considered }\end{array}$ & $\leqslant 1$ & $\% 91.1$ & $\varepsilon$ & $\% \wedge .9$ \\
\hline & \multicolumn{2}{|c|}{ Total and percentage } & rr.o & $\% \vee Y .0$ & $1 Y .0$ & $\%$ YV.O \\
\hline \multirow[t]{3}{*}{ Understanding } & 3 & $\begin{array}{l}\text { It is important } \\
\text { that the coach } \\
\text { uses analysis } \\
\text { which means }\end{array}$ & r & $\% \wedge$. & 9 & $\%$ r. \\
\hline & 4 & $\begin{array}{l}\text { Means } \\
\text { diagnosis }\end{array}$ & $r$. & $\%$ \%ч. $\vee$ & 10 & \% \\
\hline & \multicolumn{2}{|c|}{ Total and percentage } & rT & $\% V Y .0$ & Ir & $\%$ \% Y.0 \\
\hline \multirow[b]{2}{*}{ Application } & 5 & $\begin{array}{l}\text { Of the methods } \\
\text { used to } \\
\text { evaluate motor } \\
\text { performance }\end{array}$ & ro & $\% 07.7$ & $r \cdot$ & $\% \leq \varepsilon . \varepsilon$ \\
\hline & 6 & $\begin{array}{lr}\text { Most } & \text { coaches } \\
\text { use } & \text { visual } \\
\text { visualization of } \\
\text { the r desired } \\
\text { verbs } \\
\text { phases } \\
\text { compare }\end{array}$ & rᄉ & $\% \wedge \varepsilon . \varepsilon$ & v & $\% 10.7$ \\
\hline
\end{tabular}


Follow Table (8)

Frequency and percentage of correct and incorrect answers to cognitive questions in the analysis axis

\begin{tabular}{|c|c|c|c|c|c|c|}
\hline \multirow{2}{*}{$\begin{array}{ll}\text { Level } & \text { of } \\
\text { thinking } & \\
\end{array}$} & \multirow{2}{*}{ Sr. } & \multirow{2}{*}{$\begin{array}{l}\text { Cognitive } \\
\text { Questions }\end{array}$} & \multicolumn{2}{|c|}{ Correct Answers } & \multicolumn{2}{|c|}{ Incorrect Answers } \\
\hline & & & Frequency & Percentage & Frequency & Percentage \\
\hline & \multicolumn{2}{|c|}{ Total and percentage } & $r 1.0$ & $\%^{\vee \vee}$ & 15.0 & $\%^{\Gamma}$ \\
\hline \multirow[t]{3}{*}{ Analysis } & 7 & $\begin{array}{l}\text { The crucial } \\
\text { characteristics } \\
\text { of the free } \\
\text { throw in } \\
\text { basketball } \\
\text { when } \\
\text { determining } \\
\text { the target } \\
\text { (distance) is }\end{array}$ & 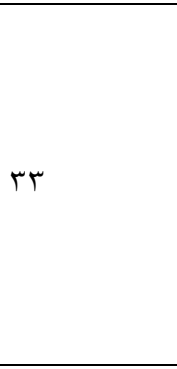 & $\% \vee r . r$ & ir & $\%$ \% . Y \\
\hline & 8 & $\begin{array}{l}\text { Cognitive } \\
\text { errors are } \\
\text { represented in }\end{array}$ & $\varepsilon r$ & $\% 90.7$ & r & $\% \varepsilon \varepsilon$ \\
\hline & \multicolumn{2}{|c|}{$\begin{array}{l}\text { Total and } \\
\text { percentage }\end{array}$} & rᄉ & $\% \wedge \varepsilon .0$ & $v$ & $\% 10.0$ \\
\hline \multirow{3}{*}{ Evaluation } & 9 & $\begin{array}{l}\text { Of basic } \\
\text { skills in the } \\
\text { diagnostic } \\
\text { task }\end{array}$ & $r \cdot$ & $\%$ \% & 10 & 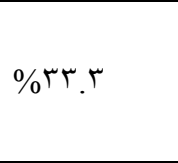 \\
\hline & 10 & $\begin{array}{l}\text { Of the } \\
\text { methods by } \\
\text { which } \\
\text { performance } \\
\text { is assessed }\end{array}$ & $\leqslant r$ & \% \% & $r$ & $\%\urcorner . \vee$ \\
\hline & \multicolumn{2}{|c|}{$\begin{array}{ll}\text { Total and } \\
\text { percentage }\end{array}$} & 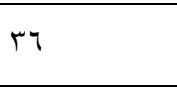 & $\% \wedge$. & 9 & $\%$ r. \\
\hline \multirow{3}{*}{$\begin{array}{l}\text { Creativity and } \\
\text { innovation }\end{array}$} & 11 & $\begin{array}{l}\text { Psychological } \\
\text { errors are } \\
\text { problems in }\end{array}$ & 1. & $\%$ Yr. $r$ & ro & $\% \vee \vee . \wedge$ \\
\hline & 12 & $\begin{array}{l}\text { Pointing to a } \\
\text { specific goal } \\
\text { that illustrates } \\
\text { the importance } \\
\text { of the base in } \\
\text { sports based on }\end{array}$ & $\leqslant r$ & $\% 90.7$ & r & $\%$ \%. \\
\hline & \multirow{2}{*}{\multicolumn{2}{|c|}{ Total and percentage }} & rч.0 & $\% 09$ & 11.0 & $\% \varepsilon 1$ \\
\hline Grand Total & & & rY.o & $\% \mathrm{VT}$ & 15.0 & $\% r v$ \\
\hline
\end{tabular}


Table (9)

The average and standard deviation of knowledge levels for Bloom's division of the observation axis for basketball coaches in Upper Egypt

\begin{tabular}{|c|c|c|c|c|}
\hline $\begin{array}{ll}\text { Level } & \text { of } \\
\text { thinking } & \end{array}$ & $\begin{array}{l}\text { Total } \\
\text { score }\end{array}$ & $\begin{array}{c}\text { Arithmetic } \\
\text { average }\end{array}$ & $\begin{array}{l}\text { standard } \\
\text { deviation }\end{array}$ & Ranking \\
\hline Analysis & 2 & 1.79 &.$\leqslant V$ & 1 \\
\hline Evaluation & 2 & 1.7. & $.0 \leqslant$ & 2 \\
\hline Understanding & 2 & $1 . \leqslant V$ &.$\vee 7$ & 3 \\
\hline Remember & 2 & $1 . \leqslant \varepsilon$ & .00 & 4 \\
\hline Application & 2 & $1 . \mu \wedge$ & .71 & 5 \\
\hline $\begin{array}{ll}\text { Creativity } & \text { and } \\
\text { innovation } & \\
\end{array}$ & 2 & 1.11 & $\because \leqslant 9$ & 6 \\
\hline $\begin{array}{ll}\text { Analysis } & \text { Axis } \\
\text { Average } & \end{array}$ & 12 & $\Lambda . \vee T$ & $1.0 Y$ & - \\
\hline
\end{tabular}

Tables (7) and (8) show that the level of cognitive outcomes of the qualitative motor analysis skills related to the analysis axis of the basketball coaches in Upper Egypt is calculated at (8.76), Where the levels of thinking about knowledge of the axis of analysis are as follows:

The general average of the total correct answers for the axis of analysis in the cognitive test was $(73 \%)$, the average of the total of the incorrect answers at the analysis axis was $(27 \%)$ and a detailed presentation of the results of the cognitive test of the levels of thinking according to the Bloom division and the special task of analysis within the tasks of qualitative motor analysis.

This indicates that the cognitive test questions for the analysis axis of the tasks of the motor analysis process in the sports field, which were developed in the light of Bloom's knowledge division in this axis, were somewhat high in the level of thinking. This shows that the level of basketball coaches in Upper Egypt in this axis is high.

The increase in the score of the basketball coaches in the cognitive test in the analysis axis at the grade (good) is a guide at the level of the basketball coaches in assessing the strengths and shortcomings of the performance, as well as the ability to determine the effectiveness of the performance and the critical points, but the failure to answer some questions this axis by $27 \%$ of the cognitive aspect of the results of this axis is due to 
the inability to use a specific scientific strategy in the analysis, but on the experience and theoretical study of the parameters of performance only.

This is consistent with Bartlett's (2007) observation that the task of analysis is divided into two independent phases, although they are interrelated (evaluating strengths and weaknesses in performance, diagnosing symptoms of weakness and preparing for treatment). (16: 54)

The researcher attributed the low level of knowledge gains of basketball coaches to the axis of "scientific and theoretical knowledge" to the low level of knowledge in that axis as well, the coach who does not have the knowledge cannot conduct successful training behavior, as "the missing thing does not give him," as indicated by Amin Khouli and Mahmoud Anan, 1999 that Cognitive Processes play a decisive role in the behavior of the individual where motor is linked to performance. (21:3)

This answers the first question. The second question: Are there differences of statistical significance in the cognitive outcomes of the skill of observation and analysis among basketball coaches in Upper Egypt due to the variables (age, qualification, number of years of experience, number of training courses)?

\section{1- Differences Upon Age:}

\section{Table (10)}

The results of the "one-way analysis of variance" of the differences in the average responses of the sample members According to the "age variable"

\begin{tabular}{|c|c|c|c|c|c|c|}
\hline Axis & $\begin{array}{c}\begin{array}{c}\text { Source } \\
\text { of }\end{array} \\
\text { variance }\end{array}$ & $\begin{array}{c}\text { Total } \\
\text { squares }\end{array}$ & $\begin{array}{c}\text { Degrees } \\
\text { of } \\
\text { freedom }\end{array}$ & $\begin{array}{l}\text { Average } \\
\text { squares }\end{array}$ & $\begin{array}{l}\text { Value } \\
\text { of }(F)\end{array}$ & $\begin{array}{c}\text { Statistical } \\
\text { significance }\end{array}$ \\
\hline \multirow{3}{*}{ Observation } & $\begin{array}{l}\text { Between } \\
\text { groups }\end{array}$ & 7.11. & 0 & I.rT & \multirow{3}{*}{$\cdot r \leqslant 0$} & \multirow{3}{*}{$\because \wedge \wedge$. } \\
\hline & $\begin{array}{l}\text { Within } \\
\text { groups }\end{array}$ & $1 r \mu_{.} \cdot 1$ & rᄉ & $r .00$ & & \\
\hline & Total & TEह. . & $\varepsilon \Gamma$ & & & \\
\hline \multirow{3}{*}{ Analysis } & $\begin{array}{l}\text { Between } \\
\text { groups }\end{array}$ & 9.7 & 0 & 1.94 & \multirow{3}{*}{.110} & \multirow{3}{*}{$.0 \leq \leqslant$} \\
\hline & $\begin{array}{l}\text { Within } \\
\text { groups }\end{array}$ & 91.7. & rᄉ & T.MT & & \\
\hline & Total & $1 \cdot 1 . r \cdot$ & $\varepsilon T$ & & & \\
\hline
\end{tabular}


It is clear from the above results that there are no statistically significant differences at the level of 0.05 and less in the cognitive outcomes among the basketball coaches in Upper Egypt according to the variable of

\section{Table (11)}

age, i.e. there are no differences in cognitive outcomes (observationanalysis) among the basketball coaches in Upper Egypt with different ages.

\section{Differences by academic qualification:}

The results of the "one-way analysis of variance" of the differences in the average responses of the sample according to the variance of academic qualification variable

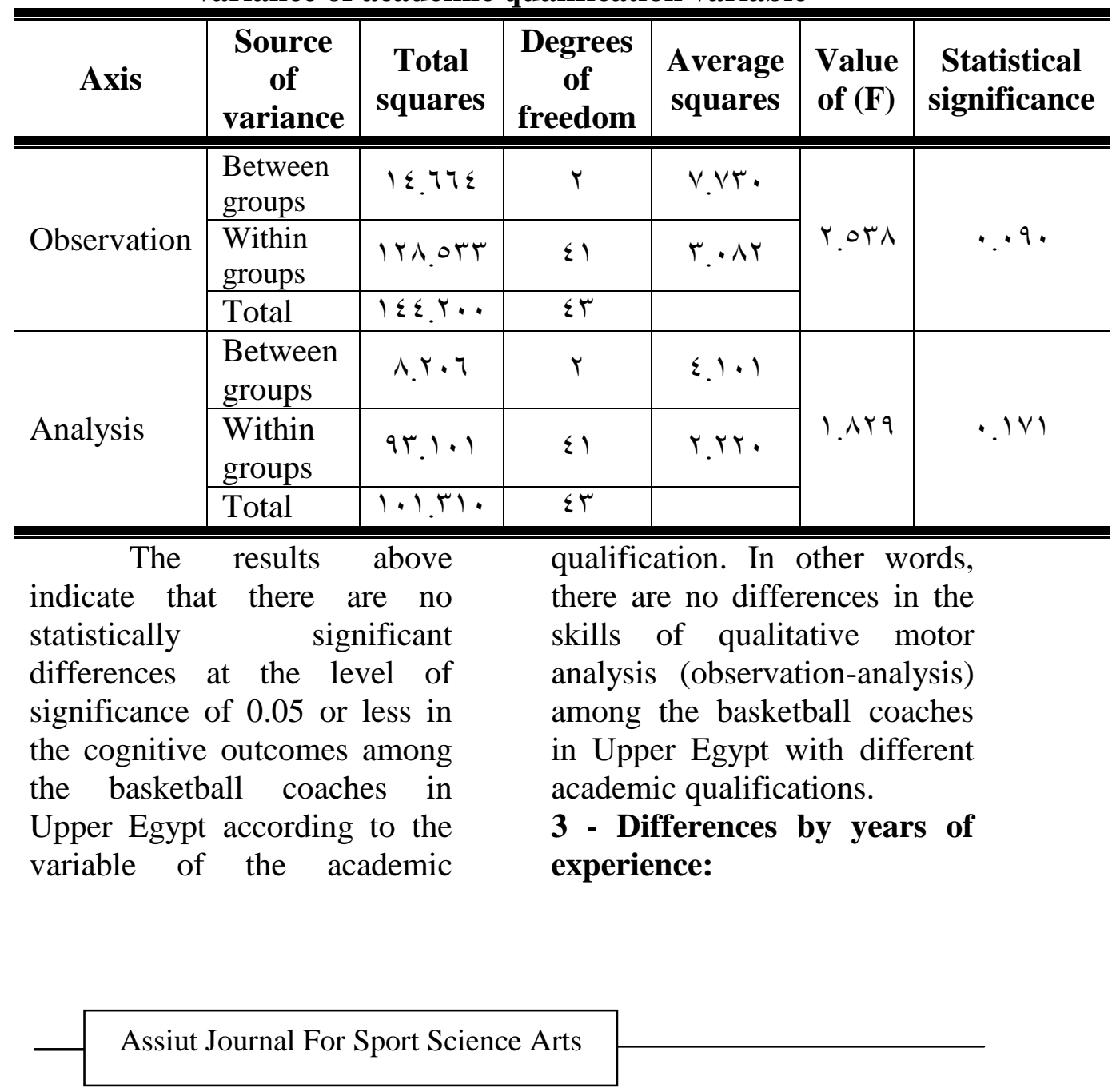


Table (12)

The results of the "one-way analysis of variance "of the differences in the average responses of the sample members according to variable of years of experience"

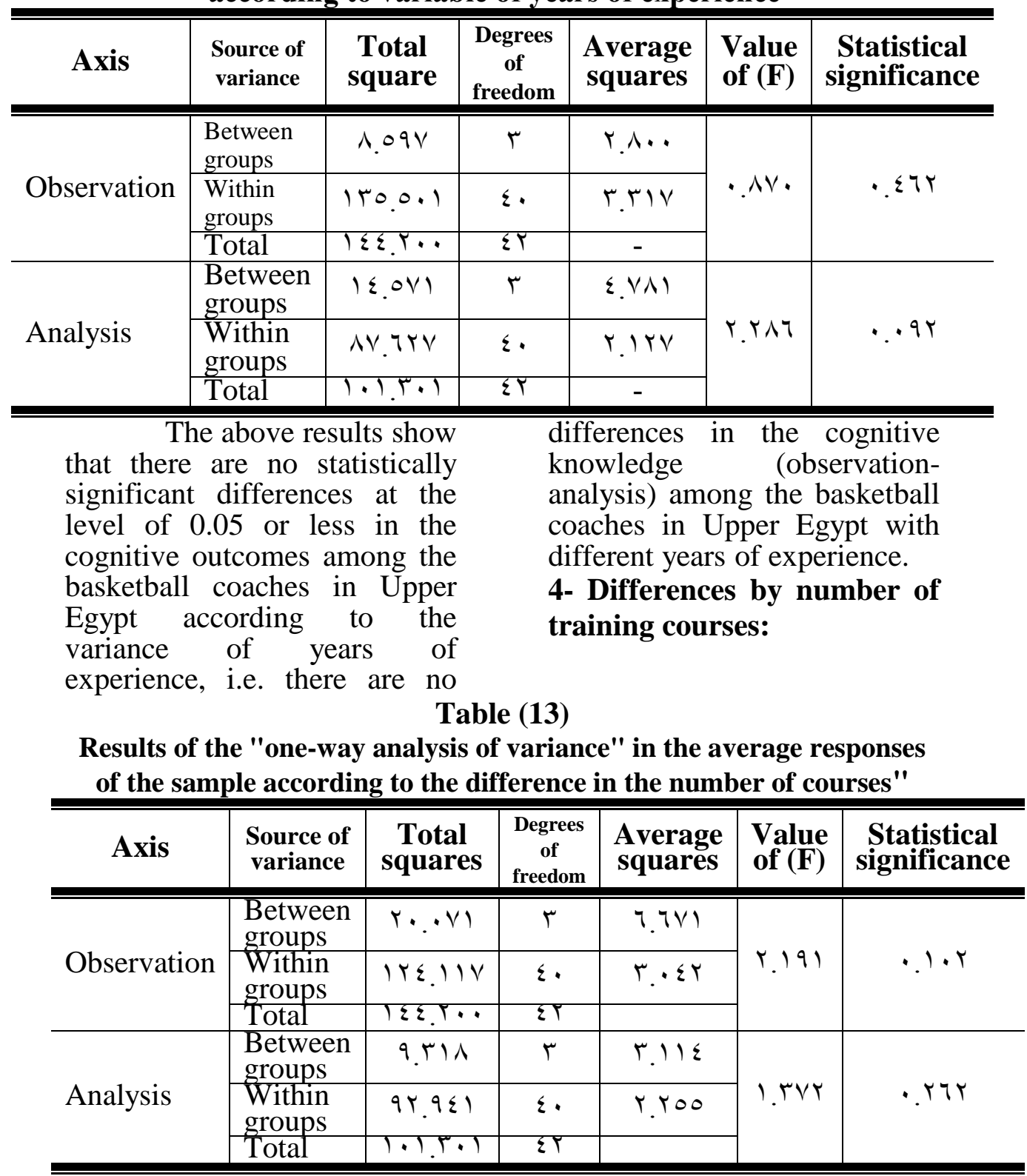

Assiut Journal For Sport Science Arts 
The results indicated above show no statistically significant differences at the level of significance of 0.05 or less in the cognitive outcomes among the basketball coaches in Upper Egypt according to the variable number of training courses, i.e. there are no differences in the skills of qualitative motor analysis (observation-analysis) among the basketball coaches in

\section{Table (14)}

Coefficient between the level of cognitive outcomes and the skills of observation and analysis $N=45$

\begin{tabular}{|c|c|c|c|}
\hline \multirow[t]{2}{*}{ Sr. } & $\begin{array}{c}\text { The skills of motor } \\
\text { analysis }\end{array}$ & \multirow[t]{2}{*}{ Observation } & \multirow[t]{2}{*}{ Analysis } \\
\hline & Knowledge levels & & \\
\hline & Analysis & $\cdot .90 \xi$ & $. \wedge 0 \leqslant$ \\
\hline & Evaluation & $\cdot .11$ &.$V 9 V$ \\
\hline & Understanding & $.91 \pi$ & $\cdot \wedge \leqslant 7$ \\
\hline & Remember & $\cdot \wedge \vee \varepsilon$ & .791 \\
\hline & Application & $\because \wedge \wedge \tau$ & $\cdot \wedge I V$ \\
\hline & Creativity and innovation & $.7 \mathrm{VV}$ & 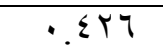 \\
\hline
\end{tabular}

The value of $\mathrm{T}$ table at 0.05 is $=0.1946$

Table (14) shows the existence of statistically significant differences between the level of knowledge and qualitative kinetic analysis skills (observation - analysis), which confirms the existence of a positive correlation between them, the low level of knowledge led to the low level
Upper Egypt according to the number of their training courses.

\section{Third: Review and discussion of the results of the third question:}

What is the relationship between cognitive outcomes and qualitative motor analysis skills (observation - analysis) of basketball coaches in Upper Egypt? 
Hamid (2005) that there is a relationship between performance and knowledge of the subject matter and confirmed by Amin Al Khuli and Mahmoud Annan (1999) that cognitive processes play a crucial role in an individual's behavior where motivation is associated with performance. (4: 155) (21:3)

This is in line with what Mohammed Alawi (1993) stated that sports knowledge is based on acquiring the correct behavior of the individual during the competitions. $\mathrm{He}$ adds that the athlete's success in his work is largely related to his knowledge, capacities and skills in the type of sports activity he specializes in. In other words, the more he understands the information and the theoretical knowledge and the methods of its application, the more he will be able to analyze the different educational and training situations and choose the most appropriate solutions to face these situations. (10: 276)

\section{Conclusions:}

The validity of the cognitive test consisting of the qualitative analysis tasks (observation, analysis) as a tool to evaluate the cognitive level associated with qualitative motor analysis of the research sample.

The number of correct answers in the cognitive test for all the subjects was $65 \%$ and the number of incorrect answers was $35 \%$. This means that the basketball coaches failed to reach the correct performance analysis by $35 \%$. This ratio is fairly high when compared to the estimate of 65\%- acceptable degree.

The level of basketball coaches in the cognitive test for the tasks of qualitative motor analysis for observation axis was less than $65 \%$ and for analysis axis was $73 \%$.

\section{Recommendations:}

Use the cognitive test consisting of the tasks of qualitative analysis (observation, analysis) applied in research as a tool to assess the level of knowledge related to the qualitative motor analysis of basketball coaches in Upper Egypt.

Design and codify more tests to evaluate the knowledge, cognitive and practical levels associated with qualitative motor analysis of basketball coaches in Upper 
Egypt with different training stages.

Include topics related to motor analysis in the preparation programs for training courses for basketball coaches in Upper Egypt.

Organize workshops and periodic education sessions by the institutions and bodies concerned to raise the level of knowledge of basketball coaches in the field of motor analysis.

\section{References:}

1- Ibrahim Eissa Mohamed Zaghari: "Problems of technical guidance for sports education for the preparatory stage of boys in the province of Qaliubia", Master of the Faculty of Physical Education for Boys, Banha University, 2008.

2- Amin El-Khouly, Mohamed Abdel-Fattah, Adnan Darwish: "School Physical Education", 2, Dar AlFikr Al-Arabi, Cairo, 1990.

3- Amin

Mahmoud

"Mathematical Knowledge", Dar Al-Fikr Al-Arabi, Cairo, 1999.

4- Jaber Abdul Hamid Jaber: "Teaching, theoretical teaching, foundations, strategies and effectiveness", First Edition, Dar Al-Fikr AlArabi, Cairo, 2005.

5- Essam El-Din Metwally: "Methods of Teaching Physical Education between Theory and Practice", Dar Al-Wafaa for Printing and Publishing, Alexandria, 2011.

6- Afaf Othman: "Effective Teaching Strategies", 1, Dar Al Wafaa Press and Publishing, Alexandria, 2014.

\section{7- Adel Ali Abdel Basir} (2004): qualitative analysis of human body movement, the Egyptian Library for Printing, Publishing and Distribution, Alexandria.

\section{8- Tariq Mohammed Jaber:}

"Synthetic Knowledge and its Relationship to the Training Behavior of Football Trainers in the Arab Republic of Egypt", Scientific Research, Assiut Journal of Sports Science and Arts, 2016.

9- Laila El Sayed Farahat: Mathematical Cognitive Measurement First Edition Book Center for Publishing Cairo, 2001.

\section{0- Mohamed Hassan Allawi:}

"Mathematical Training Science", Dar Al Ma'aref, 12th Edition, Cairo, 1993. 
11- Mohamed Hassan Allawi, Mohamed Nasr El-Din Radwan: Measurement in Physical Education and Mathematical Psychology, Dar Al-Fikr Al-Arabi, Cairo, 2000.

\section{2- Mohammed Hussein} Marzouk: "Synthetic knowledge and its relation to teaching practices of teachers of physical education" $\mathrm{PhD}$ thesis, Faculty of Physical Education Assiut University, 2015.

\section{3- Ndson And Morison} (2007): Qualitative Analysis of Human Movement, translated by Abdul Rahman bin Saad Al Anqari, Saudi Federation for Physical Education and Sport, Riyadh.

\section{4- Hisham Mohamed Abdel}

Halim: "Evaluation of the practices of directing sports education in different stages of education", Master Thesis, Faculty of Physical Education, Assiut University, 2013

\section{5- Bakhit M \& Mohamed N} (2010): The Qualitative Analysis for Evaluating the Technical Performance of Some Throwing Competitions, World Journal of Sport Sciences, Vol. 3 (S): Pp. 428436.
16- Bartlett, R.M. (2007): Introduction to Sports Biomechanics: Analyzing Human Movement Patterns, 2nd, ed., Rutledge Taylor \& Francis Group, London.

17- Capel S. A. (2004): Learning to Teach Physical Education in the Secondary School: A Companion to School Experience, 3rd, ed., Taylor \& Francis, New York.

18- El-Baroudy M. K. E., (2011): Effect of an Educational Program Using Qualitative Analysis on the Cognitive Field and the Performance of Forward Handspring on the Vault Table by the Students of the Faculty of Physical Education, Assiut University, World Journal of Sport Sciences, Vol. 4, No. 4 19- Glazier P.S (2010): Game, Set and Match? Substantive Issues and Future Directions in Performance Analysis, Sports Med.; 40 (8): 625-634

20- Glazier P. S \& Robins M.T (2012): Comment on "Use of deterministic models in sports and exercise biomechanics research" by Chow and Knudson (2011), Sports Biomechanics, March; Vol. 11, No 1, Pp. 120-122 
21- Hall S. (2011): Basic Biomechanics, 6th. ed., McGraw-Hill Education, London.

22- Knudson D. (2007): Fundamentals of Biomechanics, 2nd., ed., Lippincott Williams \& Wilkins, New York.

23- Knudson D. V. (2013): Qualitative Diagnosis of Human Movement with Web Resource-3rd Edition: Improving performance in Sport and Exercise, Human Kinetics, Champaign, IL.

24- Knudson, D., \& Morrison, C. (2002): Qualitative analysis of human movement (2nd ed.), Human Kinetics, Champaign, IL.
25- Leighton J. P. \& Gierl M. J. (2009): Cognitive diagnostic assessment for education, 2nd, ed. Cambridge university press, London.

26- Payton C. J. \&Bartlett R. M. (2008): Biomechanical Evaluation of Movement in Sport and Exercise, the British Association of Sport and Exercise Sciences Guidelines, Taylor \& Francis e-Library, New York.

27- Smith, V. K; “ A study of student attitudes and perceptions about the learning environment in a guided inquiry - based physical science course for future elementary teachers" . ERIC, No. AAC 1999. 